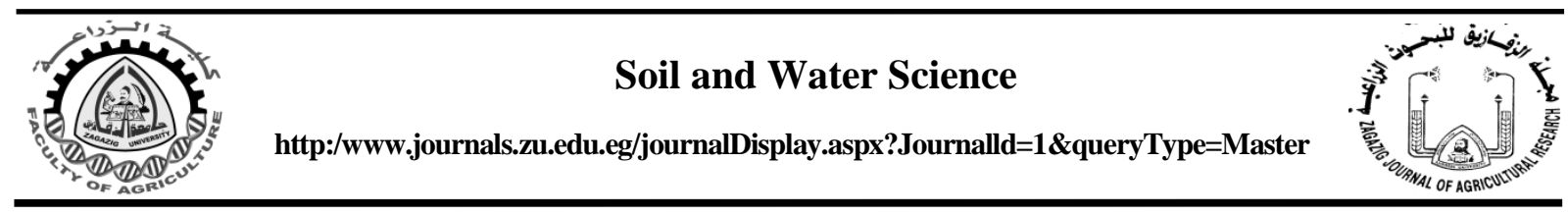

\title{
INTERACTION EFFECT OF SOME SOIL AMENDMENTS ON THE QUALITY OF SANDY SOILS CULTIVATED WITH WHEAT
}

\author{
Nesreen M.S. Mohsen ${ }^{*}$, M.N. Khalil, K.F. Moussa and E.A. El-Naka \\ Soil Sci. Dept., Fac. Agric., Zagazig Univ., Egypt
}

Received: 02/05/2017 ; Accepted: 04/06/2017

\begin{abstract}
A pot experiment was applied to investigate the effect of different amendments on some properties of sandy soil and its productivity of wheat plants. Three-factors computer model were implemented, $X_{1}$ (cheese whey + super absorbent Polymer (SAP)), $X_{2}$ (biochar + SAP) and $X_{3}$ (compost $+\mathrm{SAP}$ ). Some physical and chemical properties of sandy soil and wheat yield were estimated. The obtained results appeared that the values of bulk density, real density, porosity and moisture content (field capacity, FC, wilting point, WP, and available water, AW) of the tested soil were positively influenced by the applied soil amendments. The maximum AW was increased till $8.11 \%$ with application of 10, 10 and $80 \%$ of (cheese whey +SAP), (biochar + SAP) and (compost +SAP), respectively. Significant increases in wheat yield, were observed due to amendments addition. All the wheat growth characters showed an enhancement by the application of soil amendments as compared to the control. The maximum wheat grain yield was recorded with the application of (cheese whey+ SAP), (biochar+ SAP) and (compost+ SAP) at a rates of 10,10 and $80 \%$, respectively. This increase was 0.84 ton fad. ${ }^{-1}$ in comparison with the control.
\end{abstract}

Key words: $\mathrm{X}_{1}=$ cheese whey $+\mathrm{SAP}, \mathrm{X}_{2}=$ biochar $+\mathrm{SAP}, \mathrm{X}_{3}=$ compost $+\mathrm{SAP}$, super absorbent polymer (SAP).

\section{INTRODUCTION}

Sandy soils widely exist in arid and semi-arid regions such as the east and west desert areas of Egypt. Increasing the productivity of the lands is one of the major targets of the agricultural policy. The productivity of sandy soils is mostly limited by several agronomic obstacles. However, natural soil amendments contribute significantly to provide a reservoir of soil water to plants. In addition, soil amendments improve the water retention in dry, coarse soils likewise it showed an effective role in adjusting the $\mathrm{pH}$ of the soil. Several applications of natural soil conditioners were carried out to improve some physic-bio-chemical properties of sandy soils. Many researchers are interested in improving the physical and chemical condition of the sandy soil, thus, enhance crop production. Therefore, used natural soil amendments to improve soil structure, aeration, water-holding capacity and

\footnotetext{
*Corresponding author: Tel. :+201145567772

E-mail address: AhmedFeqy2006@yahoo.com
}

availability of water to plants were detected. Types of soil amendment, their role and the interaction between different amendments is important. In this concern, Agegnehu et al. (2015) showed that the application of natural amendments (compost and biochar) improved physical properties and nutrients availability of sandy soil and thereby uptake of water and nutrients by the plants. Demir and Gulser (2015) and Miller et al. (2015) reported that application of compost led to improve soil physical properties such as soil bulk density, plant available water (PAW), and soil water retention. Inal et al. (2015) reported that combined application of compost and biochar together increased soil physical, chemical, biological properties and plant growth. Ekebafe et al. (2013) found that application of superabsorbent polymers (SAPs) and/or biochar, increase soil fertility and agricultural yields, likewise improve soil structure, aeration and water penetration. 
On the other hand, wheat is the second most important food crop in the developing world after rice. In recent years, wheat production levels have not satisfied demand, triggering price instability and hunger riots. With a predicted world population of 9 billion in 2050, the demand for wheat is expected to increase by $60 \%$. To meet this demand, annual wheat yield increases must rise from the current level of below $1 \%$ to at least $1.6 \%$.

The objectives of this study were to evaluate the combination effect of some soil locally natural produced amendments on some chemical and physical properties of sandy soil cultivated with wheat plants as an indicator crop.

\section{MATERIALS AND METHODS}

A pot experiment was carried out to study the effect of applied some natural soil amendments. Uncultivated sandy soil of El-Khatara experimental farm were used. Some physical and chemical characters of the used sandy soil were determined and shown in Table 1.

The computer model represented by Gipesa diagram according to Moussa et al. (1986) was used in this study. This model facilitates the assessment of any three experimental factors and their interactive effect on any soil or plant for estimating the optimal combination.

In order to study the effect of various soil conditioner components on soil or plant qualitative or quantitative values, the sum of those components must be equal to 1 or $100 \%$. The three components in this study were cheese whey + Super Absorbent Polymer (SAP), biochar + SAP and compost + SAP which are designated as $X_{1}, X_{2}$ and $X_{3}$, respectively are placed at the heads of a triangle similar to that used in describing soil texture. Each factor amounts equal to $100 \%$ of its maximum value in these sites. The level of each factor decreases gradually when moving from the concerned head towards the opposite side at which the level reaches to zero, when drawing the lines representing the different levels of each factor, different intersections will result. Every intersection represents certain combination with a cost equal to $2000 \mathrm{LE} /$ faddan. Finally, the diagram will show 66 intersection points, which will cover all the possible combinations between the three factors. The triangle is divided by 9 lines parallel to the three sides. The side represents the zero level of the factor represented on the opposite head, while the following line represents $10 \%$ of the maximum value of the factor and then every following line will increase by $10 \%$ of the maximum (Fig. 1).

The actual thirteen combined treatments, which are illustrated in Fig. 2 and presented in Table 2 were chosen to carry out this experimental work. In this design the sum of the three factors will be always $100 \%$ of the maximum values, i.e., $\mathrm{X}_{1}+\mathrm{X}_{2}+\mathrm{X}_{3}=100 \%$ with a cost $=2000 \mathrm{LE} /$ faddan.

All the data obtained from the different combined treatments were passed to the computer to give the results represented on the triangle at the same site of the concerned combined treatments. These results take numbers equal to or less than 10 , and the number 10 represents the maximum value attained for this attribute. The other numbers represent values relative to maximum one.

Moreover, the program calculates the average value, determination coefficients, correlation coefficients, fisher criterion, mean square error between replicates, $t$ criterion for control and maximum and minimum values of the attribute. Table 3 describe some properties of the cheese whey, biochip and compost.

Plastic pots of $25 \mathrm{~cm}$ height and $21 \mathrm{~cm}$ diameter were filled with $10 \mathrm{~kg}$ soil for each, mixed with appropriate level of soil amendment as described in Table 2. Soil amendments (cheese whey + SAP, biochar + SAP and compost + SAP) were applied before wheat cultivation and thoroughly mixed well with the soil surface layer $(0-15 \mathrm{~cm})$. Four replicates of each treatment were applied. The pots were planted with 20 wheat grains (Tritcium vulgar C.V., Sakha 93) thinned to 5 plants per pot. All the treatments were received recommended dose of the mineral fertilizer according to the program of Egyptian Ministry of Agriculture.

The following growth characters, grain yield (ton/ feddan), weight of 1000 grains (g), spike length $(\mathrm{cm})$ and plant height $(\mathrm{cm})$ were recorded according to Cottenie et al. (1982). After harvesting soil samples were taken for physical and chemical analyses. 
Zagazig J. Agric. Res., Vol. 44 No. (4) 2017

Table 1. Some physical and chemical properties of the experimental soil

\begin{tabular}{|c|c|c|c|}
\hline Soil characteristics & Values & Soil characteristics & Values \\
\hline $\begin{array}{l}\text { Particle size distribution (\%) } \\
\text { (\%) }\end{array}$ & & Physical properties & \\
\hline sand & 90.30 & Saturation percent (\%) & 18.00 \\
\hline Silt & 5.94 & Available water AW (\%) & 4.92 \\
\hline Clay & 3.76 & Field capacity FC (\%) & 6.54 \\
\hline \multirow[t]{5}{*}{ Texture class } & Sandy & Wilting point WP (\%) & 1.62 \\
\hline & & Air dried soil moisture (\%) & 0.46 \\
\hline & & Bulk density $\left(\mathrm{g} \mathrm{cm}^{-3}\right)$ & 1.72 \\
\hline & & Real density $\left(\mathrm{g} \mathrm{cm}^{-3}\right)$ & 2.74 \\
\hline & & Total porosity (\%) & 37.00 \\
\hline Chemical properties & & Soluble cations and anions & \\
\hline $\mathrm{CaCO}_{3}(\%)$ & 0.37 & $\left(\operatorname{meq~} \mathbf{L}^{-1}\right)$ & \\
\hline pH (1:2.5 soil water suspension) & 8.45 & $\mathbf{C a}^{++}$ & 1.80 \\
\hline EC, dS $\mathrm{m}^{-1}$ (saturated paste extract) & 0.70 & $\mathbf{M g}^{++}$ & 3.64 \\
\hline Organic matter $\left(\mathrm{g} \mathrm{kg}^{-1}\right)$ & 0.50 & $\mathrm{Na}^{+}$ & 0.84 \\
\hline Available macronutrients $\left(\mathrm{mg} \mathrm{Kg}^{-1}\right)$ & & $\mathbf{K}^{+}$ & 0.42 \\
\hline $\mathbf{N}$ & 20.53 & $\mathrm{CO}_{3}^{--}$ & - \\
\hline $\mathbf{P}$ & 1.37 & $\mathrm{HCO}_{3}^{-}$ & 1.54 \\
\hline \multirow[t]{2}{*}{$\mathbf{K}$} & 59.69 & $\mathrm{CL}^{-}$ & 1.40 \\
\hline & & $\mathrm{SO}_{4}^{--}$ & 3.76 \\
\hline
\end{tabular}
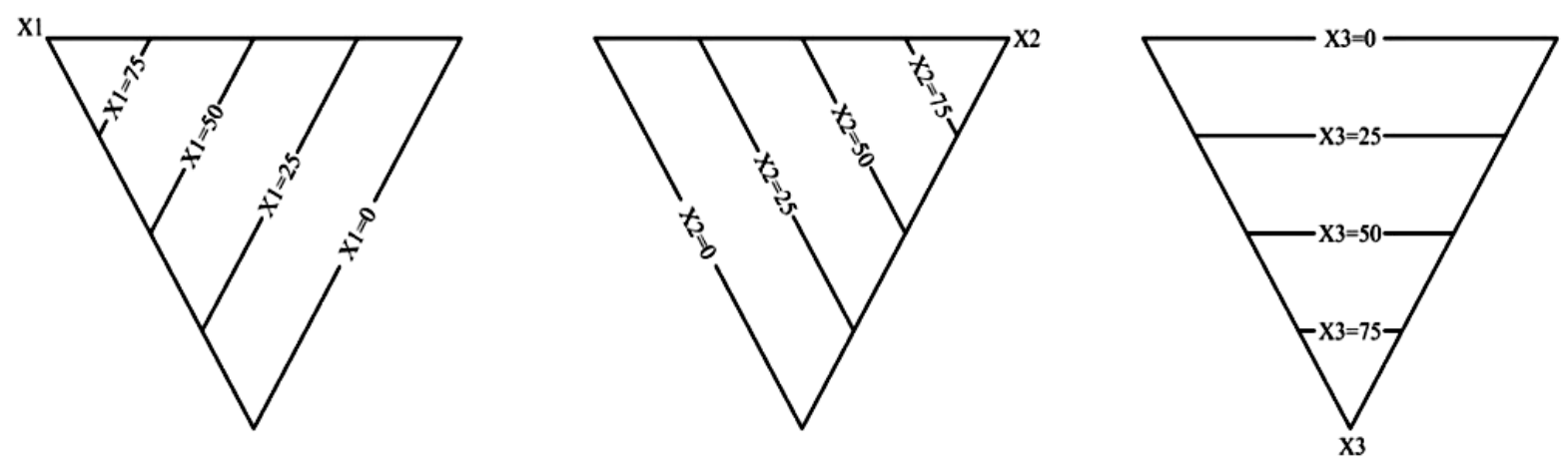

Fig. 1. Gipesa diagram 


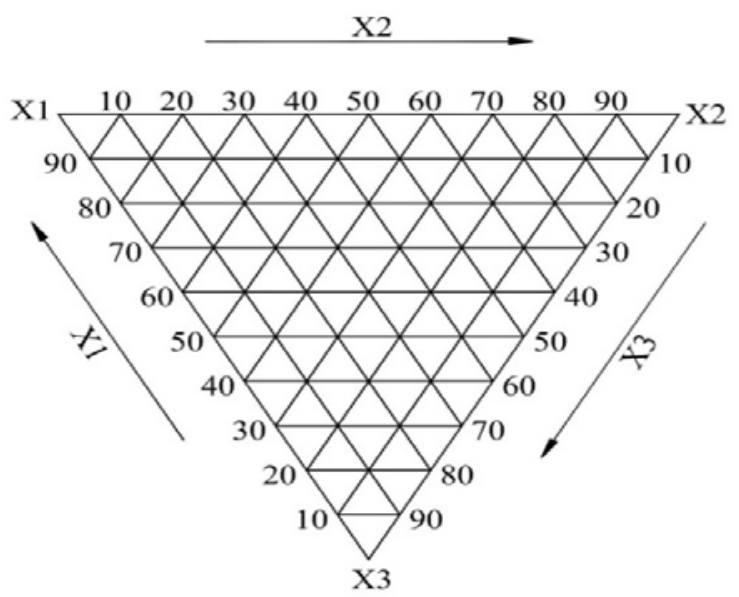

Fig. 2. Guide for the $\left(X_{1}\right),\left(X_{2}\right)$ and $\left(X_{3}\right)$ point combination of each treatment on triangle diagram

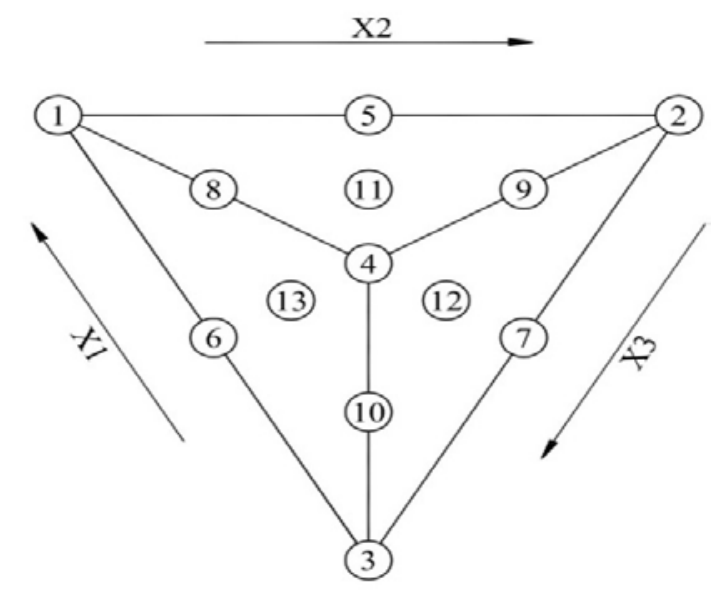

Fig. 3. Chosen Location of the thirteen treatments

Table 2. The thirteen chosen treatments as percentages and $\mathrm{Kg} \mathrm{fad}^{-1}$

\begin{tabular}{|c|c|c|c|c|c|c|c|c|c|}
\hline \multirow[t]{3}{*}{$\begin{array}{c}\text { Treat. } \\
\text { No. }\end{array}$} & \multicolumn{3}{|c|}{$\begin{array}{c}\text { Treatments as } \\
\text { percentages (\%) }\end{array}$} & \multicolumn{6}{|c|}{ Treatments as amount } \\
\hline & \multirow[t]{2}{*}{$\left(X_{1}\right)$} & \multirow[t]{2}{*}{$\left(X_{2}\right)$} & \multirow[t]{2}{*}{$\left(X_{3}\right)$} & \multicolumn{2}{|c|}{$\left(X_{1}\right)$} & \multicolumn{2}{|c|}{$\left(X_{2}\right)$} & \multicolumn{2}{|c|}{$\left(X_{3}\right)$} \\
\hline & & & & $\begin{array}{c}\text { Cheese whey } \\
\left.\text { (kg fad. }^{-1}\right)\end{array}$ & 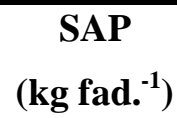 & $\begin{array}{c}\text { Biochar } \\
\left.\text { (kg fad. }^{-1}\right)\end{array}$ & $\begin{array}{c}\text { SAP } \\
\left(\mathrm{kg} \mathrm{fad}^{-1}\right)\end{array}$ & $\begin{array}{l}\text { Compost } \\
\left(\text { kg fad. }^{-1}\right)\end{array}$ & 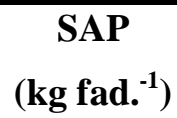 \\
\hline 1 & 100 & 0 & 0 & 131.5 & 5.5 & 0 & 0 & 0 & 0 \\
\hline 2 & 0 & 100 & 0 & 0 & 0 & 500 & 5.5 & 0 & 0 \\
\hline 3 & 0 & 0 & 100 & 0 & 0 & 0 & 0 & 5000 & 5.5 \\
\hline 4 & 33.3 & 33.3 & 33.3 & 43.78 & 1.83 & 166.5 & 1.83 & 1665 & 1.83 \\
\hline 5 & 50 & 50 & 0 & 65.75 & 2.75 & 250 & 2.75 & 0 & 0 \\
\hline 6 & 50 & 0 & 50 & 65.75 & 2.75 & 0 & 0 & 2500 & 2.75 \\
\hline 7 & 0 & 50 & 50 & 0 & 0 & 250 & 2.75 & 2500 & 2.75 \\
\hline 8 & 66.6 & 16.6 & 16.6 & 87.57 & 3.66 & 83 & 0.91 & 830 & 0.91 \\
\hline 9 & 16.6 & 66.6 & 16.6 & 21.82 & 0.91 & 333 & 3.66 & 830 & 0.91 \\
\hline 10 & 16.6 & 16.6 & 66.6 & 21.82 & 0.91 & 83 & 0.91 & 3330 & 3.66 \\
\hline 11 & 44.4 & 44.4 & 11.1 & 58.38 & 2.44 & 222 & 2.44 & 555 & 0.61 \\
\hline 12 & 44.4 & 11.1 & 44.4 & 58.38 & 2.44 & 55.5 & 0.61 & 2220 & 2.44 \\
\hline 13 & 11.1 & 44.4 & 44.4 & 14.59 & 0.61 & 222 & 2.44 & 2220 & 2.44 \\
\hline
\end{tabular}


Zagazig J. Agric. Res., Vol. 44 No. (4) 2017

Table 3. Some physical and chemical characteristics of the used soil amendments

\begin{tabular}{|c|c|c|c|}
\hline \multirow[t]{2}{*}{ Character } & \multicolumn{3}{|c|}{ Soil amendments } \\
\hline & Cheese whey & Biochar & Compost \\
\hline pH (1:2.5 water suspension) & 6.42 & 8.53 & 7.23 \\
\hline $\mathrm{EC}\left(\mathrm{dSm}^{-1}\right)$ & 7.21 & 4.22 & 3.30 \\
\hline Organic matter ( g kg $\left.^{-1}\right)$ & 591.90 & 15.60 & 290.40 \\
\hline Organic carbon ( $\mathrm{g} \mathrm{kg}^{-1}$ ) & 343.3 & 9.70 & 168.45 \\
\hline Total N (g kg $\left.{ }^{-1}\right)$ & 18.00 & 10.9 & 10.00 \\
\hline $\mathrm{C} / \mathrm{N}$ ratio & 19.10 & 0,90 & 16.85 \\
\hline$P\left(\mathrm{~g} \mathrm{~kg}^{-1}\right)$ & 6.00 & 0.70 & 1.10 \\
\hline$K\left(\mathrm{~g} \mathrm{~kg}^{-1}\right)$ & 21.70 & 11.00 & 13.00 \\
\hline Moisture content (\%) & - & - & 25.00 \\
\hline Weight of $1 \mathbf{~ m}^{3}$ ( kg) & - & - & 650 \\
\hline
\end{tabular}

Bulk density $\left(\mathrm{g} \mathrm{cm}^{-3}\right)$, real density $\left(\mathrm{g} \mathrm{cm}^{-3}\right)$, total porosity (\%) and air dried soil moisture (\%) were determined according to Baruah and Barthakur (1997). Available water (\%), field capacity (\%) and wilting point (\%) according to Deleenheer and De Boodt (1965). Electrical conductivity (EC) according to Jackson (1973). Soil pH according to Cottenie et al. (1982). Soluble cations and anions according to Black (1965). Sodium and potassium were estimated as described by Cottenie et al. (1982). Calcium, magnesium and organic matter according to Jackson (1973).

\section{RESULTS AND DISCUSSION}

Values of bulk density, real density and total porosity of the tested soil were positively influenced by the application of $\mathrm{X}_{1}$ (cheese whey + SAP), $X_{2}$ (biochar + SAP) and $X_{3}$ (compost + SAP) to the soil. Table 4 and Fig. 4 show that soil real density as affected by different combinations of (cheese whey + SAP), (biochar + SAP) and (compost + SAP) is ranged between 2.55 to $2.63 \mathrm{~g} \mathrm{~cm}^{-3}$ while control recorded $2.74 \mathrm{~g}$ $\mathrm{cm}^{-3}$. Scanning the different treatments, it could be detected that the most effective treatments was the single application of (compost + SAP) which induced a reduction in soil real density from $2.74 \mathrm{~g} \mathrm{~cm}^{-3}$ to $2.55 \mathrm{~g} \mathrm{~cm}^{-3}$. The reduction of soil real density associated with the compost application may be due to the law density of the applied compost $\left(0.19 \mathrm{~g} \mathrm{~cm}^{-3}\right)$. The other single treatments of (cheese whey + SAP), and (biochar + SAP) achieved a reduction in soil real density as compared to the control. This reduction took the following descending order $($ compost $+\mathrm{SAP})>($ biochar $+\mathrm{SAP})>$ (cheese whey + SAP). Fig. 4 illustrated that there was a very little change in soil real density (No9) occupied all the triangle area, which means that the change in soil real density was only in the second decimal number.

Soil bulk density is one of the most effective parameters which improve soil physical properties. Table 4 and Fig. 5 show that soil bulk density was affected by different combinations of (cheese whey +SAP), (biochar + SAP) and (compost +SAP). Wherever, it was ranged from 1.52 to $1.64 \mathrm{~g} \mathrm{~cm}^{-3}$ compared to the control $\left(1.72 \mathrm{~g} \mathrm{~cm}^{-3}\right)$.The individual application of (cheese whey +SAP), (biochar + SAP) and (compost +SAP) resulted 1.64, 1.62 and $1.52 \mathrm{~g}$ $\mathrm{cm}^{-3}$, respectively. These results appeared the effective role of compost +SAP in reducing soil bulk density compared with (cheese whey + SAP) or (biochar + SAP). Fig. 5 reveal that there are no big changes in soil bulk density as affected by the used amendments in which No. 9 occupied all the triangle area as that of real density. 
Table 4. Some soil physical properties and moisture relations as affected by different combination of used amendments

\begin{tabular}{|c|c|c|c|c|c|c|c|c|c|c|c|c|c|}
\hline \multirow{2}{*}{$\begin{array}{c}\text { Treat. } \\
\text { No. }\end{array}$} & \multicolumn{3}{|c|}{ Treatment percentages $\%$} & \multirow[t]{2}{*}{ pH } & \multirow{2}{*}{$\begin{array}{c}\text { EC, } \\
\text { dS.m }\end{array}$} & \multirow{2}{*}{$\begin{array}{c}\text { Bulk } \\
\text { density } \\
\left(\text { g.cm }^{-3}\right)\end{array}$} & \multirow{2}{*}{$\begin{array}{l}\text { Real density } \\
(\text { g.cm } \\
\text { (g.- })\end{array}$} & \multirow{2}{*}{$\begin{array}{c}\text { Total } \\
\text { porosity } \\
(\%)\end{array}$} & \multirow{2}{*}{$\begin{array}{l}\text { OM } \\
(\%)\end{array}$} & \multirow{2}{*}{$\begin{array}{c}\text { Soil maximum } \\
\text { water holding } \\
\text { capacity } \\
\text { (\%) } \\
\end{array}$} & \multirow{2}{*}{$\begin{array}{c}\text { Soil } \\
\text { field capacity } \\
\text { (\%) }\end{array}$} & \multirow{2}{*}{$\begin{array}{c}\text { Soil } \\
\text { wilting } \\
\text { point (\%) }\end{array}$} & \multirow{2}{*}{$\begin{array}{c}\text { Soil } \\
\text { available } \\
\text { water } \\
(\%) \\
\end{array}$} \\
\hline & $\begin{array}{c}\mathrm{X}_{1} \\
\text { Chese whey +sap }\end{array}$ & $\begin{array}{c}\mathrm{X}_{2} \\
\text { Biochar+SAP }\end{array}$ & $\begin{array}{c}X_{3} \\
\text { Compost+SAP }\end{array}$ & & & & & & & & & & \\
\hline 1 & 100 & 0.0 & 0.0 & 7.90 & 1.08 & 1.64 & 2.62 & 37.40 & 0.12 & 20.43 & 11.19 & 5.06 & 6.13 \\
\hline 2 & 0.0 & 100 & 0.0 & 8.37 & 0.85 & 1.62 & 2.63 & 38.36 & 0.11 & 23.49 & 12.93 & 6.00 & 6.93 \\
\hline 3 & 0.0 & 0.0 & 100 & 8.27 & 1.42 & 1.52 & 2.55 & 42.09 & 0.20 & 29.37 & 15.18 & 7.33 & 7.85 \\
\hline 4 & 33.3 & 33.3 & 33.3 & 7.87 & 1.02 & 1.60 & 2.59 & 38.12 & 0.10 & 22.39 & 11.25 & 5.16 & 6.09 \\
\hline 5 & 50 & 50 & 0.0 & 7.81 & 0.93 & 1.63 & 2.60 & 37.65 & 0.14 & 21.27 & 12.23 & 6.01 & 6.22 \\
\hline 6 & 50 & 0.0 & 50 & 7.93 & 1.95 & 1.58 & 2.58 & 38,46 & 0.12 & 23.26 & 13.05 & 7.07 & 5.98 \\
\hline 7 & 0.0 & 50 & 50 & 8.23 & 0.97 & 1.57 & 2.58 & 38.91 & 0.14 & 21.14 & 11.04 & 5.03 & 6.01 \\
\hline 8 & 66.6 & 16.6 & 16.6 & 7.91 & 1.35 & 1.61 & 2.59 & 37.92 & 0.15 & 20.65 & 11.62 & 6.04 & 5.58 \\
\hline 9 & 16.6 & 66.6 & 16.6 & 8.15 & 0.79 & 1.61 & 2.60 & 38.34 & 0.12 & 19.18 & 10.12 & 5.07 & 5.05 \\
\hline 10 & 16.6 & 16.6 & 66.6 & 8.14 & 1.42 & 1.56 & 2.56 & 39.02 & 0.16 & 28.68 & 14.93 & 7.03 & 7.90 \\
\hline 12 & 44.4 & 11.1 & 44.4 & 8.11 & 1.79 & 1.60 & 2.58 & 37.75 & 0.15 & 23.69 & 12.30 & 6.21 & 6.09 \\
\hline 13 & 11.1 & 44.4 & 44.4 & 8.35 & 1.90 & 1.59 & 2.56 & 38.35 & 0.14 & 24.42 & 13.76 & 6.43 & 7.33 \\
\hline \multirow[t]{2}{*}{ Control } & & & & 8.45 & 0.70 & 1.72 & 2.74 & 37.00 & 0.05 & 18.4 & 6.54 & 1.62 & 4.92 \\
\hline & & & & & & $*_{-0.89}$ & $*_{-} 0.62$ & - & & $* * 0.90$ & $* * 0.93$ & $* * 0.72$ & - \\
\hline
\end{tabular}




\section{AVERAGE VALUES}

$\begin{array}{lllll}1 & 2.60 & 2.62 & 2.64 & 2.62= \\ 2 & 2.62 & 2.64 & 2.63 & 2.64=2.6200 \\ 3 & 2.56 & 2.54 & 2.57 & 2.54=2.5325 \\ 4 & 2.58 & 2.60 & 2.59 & 2.59=2.5900 \\ 5 & 2.63 & 2.58 & 2.61 & 2.64=2.6025 \\ 6 & 2.58 & 2.60 & 2.59 & 2.55=2.5800 \\ 7 & 2.58 & 2.60 & 2.60 & 2.55=2.5825 \\ 8 & 2.60 & 2.60 & 2.61 & 2.58=2.5975 \\ 9 & 2.60 & 2.62 & 2.61 & 2.59=2.6050 \\ 10 & 2.55 & 2.58 & 2.57 & 2.55=2.5625 \\ 11 & 2.61 & 2.59 & 2.63 & 2.61=2.5975 \\ 12 & 2.58 & 2.57 & 2.58 & 2.60=2.5825 \\ 13 & 2.59 & 2.59 & 2.60 & 2.57=2.5675\end{array}$

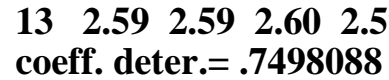

correlation function $=\mathbf{. 8 6 5 9 1 4 9}$

criterion fisher $f(12,39)=9.740062$

soct $=1.441877 \mathrm{E}-02$

control=-2.722216E-02

$t=.4028099$

control $=-2.606944$

$\mathbf{t}=38.5753$

control $=-5.195833$

$\mathrm{t}=\mathbf{7 6 . 8 8 3 4 3}$

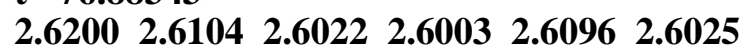

$\begin{array}{llllll}2.6047 & 2.6088 & 2.6148 & 2.6227 & 2.6325\end{array}$

$\begin{array}{llllll}2.6110 & 2.6047 & 2.5990 & 2.5989 & 2.6091 & 2.5989\end{array}$

$\begin{array}{llll}2.6022 & 2.6074 & 2.6145 & 2.6209\end{array}$

$\begin{array}{llllll}2.6025 & 2.5987 & 2.5948 & 2.5956 & 2.5941 & 2.5966\end{array}$

$\begin{array}{llll}2.6010 & 2.5975 & 2.6101\end{array}$

$\begin{array}{llllll}2.5945 & 2.5925 & 2.5894 & 2.5903 & 2.5920 & 2.5849\end{array}$

2.58332 .6001

$\begin{array}{llllll}2.5870 & 2.5859 & 2.5829 & 2.5831 & 2.5737 & 2.5721\end{array}$

2.5909

$\begin{array}{llllll}2.5800 & 2.5790 & 2.5753 & 2.5677 & 2.5638 & 2.5825\end{array}$

$\begin{array}{lllll}2.5735 & 2.5718 & 2.5666 & 2.5584 & 2.5749\end{array}$

$\begin{array}{llll}2.5675 & 2.5642 & 2.5560 & 2.5681\end{array}$

$\begin{array}{llll}2.5620 & 2.5564 & 2.5621\end{array}$

2.55702 .5569

2.5525

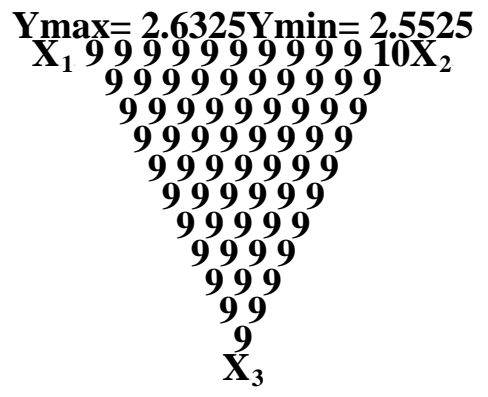

Fig. 4. Soil real density g.cm ${ }^{-3}$, as affected by cheese whey + SAP, biochar + SAP and compost + SAP. $Y$ max $=X_{1}=0, X_{2}=100, X_{3}=0 Y \min =X_{1}=0, X_{2}=0, X_{3}=100$ 
AVERAGE VALUES
$11.631 .641 .651 .64=1.6400$
$\begin{array}{lllll}2 & 1.61 & 1.62 & 1.64 & 1.62=1.6225\end{array}$
$\begin{array}{lllll}3 & 1.53 & 1.51 & 1.53 & 1.52=1.5225\end{array}$
$\begin{array}{lllll}4 & 1.61 & 1.61 & 1.59 & 1.60\end{array}$
$\begin{array}{lllll}5 & 1.631 .62 & 1.64 & 1.63=1.6300\end{array}$
$\begin{array}{lllll}6 & 1.60 & 1.59 & 1.59 & 1.57=1.5875\end{array}$
$\begin{array}{lllll}7 & 1.581 .591 .58 & 1.56=1.5775\end{array}$
$81.601 .611 .631 .61=1.6125$
$91.611 .621 .621 .60=1.6125$
$101.541 .591 .551 .57=1.5625$
$111.631 .601 .621 .63=1.6200$
$121.601 .611 .601 .62=1.6075$
$131.611 .581 .591 .60=1.5950$
coeff. deter. $=\mathbf{. 8 8 7 8 3 3 1}$

correlation function $=\mathbf{. 9 4 2 2 4 8 9}$

criterion fisher $f(12,39)=25.72469$

soct $=1.240401 \mathrm{E}-02$

control=-3.944433E-02

$t=.6292818$

control $=-1.621389$

$t=25.86711$

control $=-3.195833$

$\mathbf{t}=\mathbf{5 0 . 9 8 5 2 7}$

$\begin{array}{llllll}1.6400 & 1.6170 & 1.5860 & 1.5668 & 1.5790 & 1.6300\end{array}$

$\begin{array}{lllll}1.6283 & 1.6267 & 1.6252 & 1.6238 & 1.6225\end{array}$

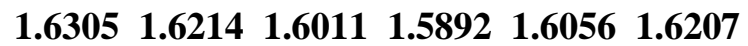

$\begin{array}{llll}1.6197 & 1.6182 & 1.6165 & 1.6143\end{array}$

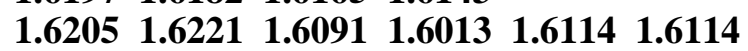

1.61051 .61271 .6057

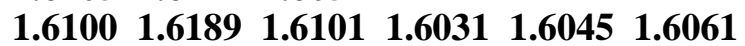

1.60681 .5967

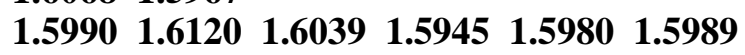

1.5873

$\begin{array}{llllll}1.5875 & 1.6013 & 1.5908 & 1.5861 & 1.5889 & 1.5775\end{array}$

$\begin{array}{lllll}1.5755 & 1.5868 & 1.5705 & 1.5768 & 1.5673\end{array}$

$\begin{array}{llll}1.5630 & 1.5686 & 1.5627 & 1.5567\end{array}$

$\begin{array}{lll}1.5500 & 1.5465 & 1.5457\end{array}$

1.53651 .5343

1.5225

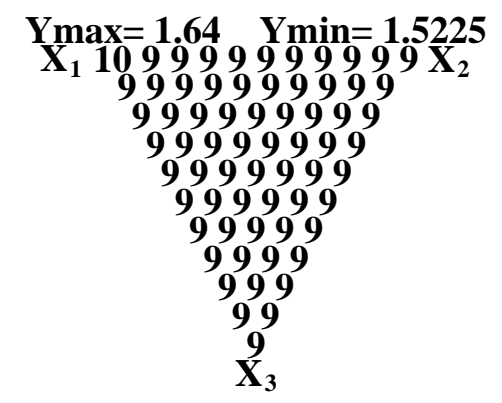

Fig. 5. Soil bulk density g.cm ${ }^{-3}$, as affected by cheese whey + SAP, biochar + SAP and compost + SAP after wheat crop. $Y$ max $=X_{1}=100, X_{2}=0, X_{3}=0 Y$ min $=X_{1}=0, X_{2}=0, X_{3}=100$ 
The obtained results in Table 4 and Fig. 6 demonstrate that the total soil porosity ranged from 37.40 to $42.09 \%$, as affected by different combinations of (cheese whey +SAP), (biochar + SAP) and (compost +SAP), that appeared the effective role of (compost + SAP) on raising the soil porosity by more that $13.7 \%$ compared to the control (37\%). It is ought to be mentioned herein that the most positive effect of the first three treatments received the maximum dose of (cheese whey +SAP), (biochar + SAP) and (compost $+\mathrm{SAP}$ ) followed the order (compost $+\mathrm{SAP})>$ (biochar + SAP) $>$ (cheese whey + SAP), which mean that application of $100 \% \mathrm{X}_{1}$, $\mathrm{X}_{2}$ and $\mathrm{X}_{3}$ as a single treatment resulted in 80, 90 and $100 \%$ of the maximum total porosity, respectively. These results once more obvious the favorable use of compost.

Soil $\mathrm{pH}$ is contributing soil nutrients solubility and availability to plant and may effects soil microorganism. Soil $\mathrm{pH}$ as affected by different combinations of $\mathrm{X}_{1}$ (cheese whey + SAP), $X_{2}$ (biochar + SAP) and $X_{3}$ (compost + SAP) are manifested in Table 5 and Fig. 7 is ranged between 7.81 and 8.37 , while the value recorded at the control was 8.45 . Soil $\mathrm{pH}$ values showed a reduction after wheat crop as a result of added amendments as compared to the control. The minimum $\mathrm{pH}$ value was occurred with the treatment of $60 \%$ (cheese whey + SAP) $+40 \%$ (biochar + SAP). On the other hand, the maximum $\mathrm{pH}$ value was induced with (biochar + SAP) treatments. The obtained results pointed out that the $\mathrm{pH}$ of the soil received (cheese why + SAP), (biochar+ SAP) and (compost + SAP) were $7.90,8.37$, and 8.27 , respectively.

The $\mathrm{pH}$ values decreased gradually in the triangle Fig. 7 from $X_{2}$ toward $X_{1}$, which refer to the beneficial effects of applied organic amendment to reduce soil $\mathrm{pH}$, specially cheese whey. The relationship between application of organic amendment and soil reaction are due to $\mathrm{CO}_{2}$ and organic acids which produced during the decomposition of organic materials.

Many workers reported that organic manure affected the soil pH, El-Fayoumy et al. (2000), Mahmoud (2000), Basyouny (2002), El-Maddah (2005) and Wahdan et al. (2005), they reported that increasing the applied organic manure rates resulted in an increase of soil organic matter content as well as a decrease of soil $\mathrm{pH}$.
Electrical conductivity is a soil parameter that indicates indirectly the total concentration of soluble salts and is a direct measurement of salinity. Results illustrated in Table 4 and Fig. 8 declare that soil electrical conductivity was affected by the different combinations of (cheese whey + SAP), (biochar + SAP), and (compost +SAP). Electrical conductivity was ranged from 1.95 to $0.79 \mathrm{dSm}^{-1}$ compared with control which recorded $0.70 \mathrm{dSm}^{-1}$. These results pointed out that application of such amendments led to increase soil electrical conductivity. Moreover, Table 4 reveals that EC of the first three individual treatments which received only the maximum dose of (cheese whey + SAP), (biochar +SAP), or (compost +SAP) recorded decreased in soil EC to 1.08, 0.85 and $1.42 \mathrm{dSm}^{-1}$, respectively. In other words the individual treatments which received the maximum dose of (cheese whey + SAP), (biochar + SAP) and (compost $+\mathrm{SAP}$ ) resulted as EC values equal to 50,40 and $70 \%$ of the maximum EC value. The maximum value is denoted by No.10 and obtained with 40,0 and $60 \%$ of $\left(\mathrm{X}_{1}, \mathrm{X}_{2}\right.$ and $\left.\mathrm{X}_{3}\right)$, respectively. Scanning the other EC values of Fig.(8) it could be recognized that the minimum soil EC value denoted by No.1on the triangle $\left(0.32 \mathrm{dSm}^{-1}\right)$ resulted from application of 60,40 and $0 \%$ of $X_{1}$ (cheese whey + SAP), $X_{2}$ (biochar + SAP), and $\mathrm{X}_{3}$ (compost +SAP), respectively. It is seem that the combination effect between cheese whey and biochar has a marked decreasing on soil electrical conductivity compared with other combinations.

However, the addition of (biochar +SAP) to the soils led to slightly increased in EC values compared with control, the soils amended with (cheese whey +SAP) and (compost +SAP) showed a higher EC than the untreated soils. These results suggested that application of compost induced an increase in soil salinity.

Thus, the decrease effectiveness took the following descending order (biochar +SAP) > (cheese whey $+\mathrm{SAP})>($ compost $+\mathrm{SAP})$.

Similar results have been reported by Sarwar et al. (2003), Niklasch and Joergensen (2001), Selvakumari et al. (2000) and Gonzalez et al. (2010), which indicated that EC increased in acidic as well as alkaline soils when organic materials of different nature were applied to the soil. 


\section{AVERAGE VALUES}

$137.3037 .4037 .5037 .40=37.4000$

$238.5538 .6337 .6438 .63=38.3625$

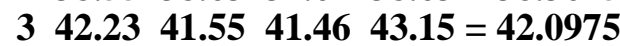

$437.5938 .0838 .6138 .22=38.1250$

$538.0237 .2037 .1638 .25=37.6575$

$637.9838 .8438 .6138 .43=38.4650$

$738.7538 .8439 .23 \quad 38.82=38.9100$

$838.4638 .0837 .5537 .60=37.9225$

$938.0738 .1638 .9338 .22=38.3450$

$1039.6038 .3739 .6938 .43=39.0225$

$1137.5438 .2238 .4037 .55=37.9275$

$1237.9837 .3537 .9837 .69=37.7500$

$1337.8338 .9938 .8437 .74=38.3500$

coeff. deter. $=.877998$

correlation function $=\mathbf{. 9 3 7 0 1 5 5}$

criterion fisher $f(12,39)=23.38891$

soct $=\mathbf{. 4 8 8 3 0 7 3}$

control $=.2788887$

$\mathrm{t}=.7091303$

control $=-38.28222$

$\mathbf{t}=\mathbf{9 7 . 3 4 0 1 9}$

control=-76.90166

$\mathbf{t}=\mathbf{1 9 5 . 5 3 7 8}$

37.4000 38.1501 39.186540 .048440 .274837 .6575

37.7627 37.8858 38.0268 38.1857 38.3625

37.407637 .751938 .459439 .069139 .120337 .9511

38.0666 38.2083 38.3763 38.2608

37.5179 37.5333 37.9886 38.4230 38.0836 38.1831

38.3172 38.2159 38.2647

37.7309 37.4941 37.7742 38.1101 38.1852 38.1725

38.186038 .3742

38.0466 37.6345 37.816038 .130338 .182838 .2863

38.5893

38.4650 37.9544 38.1143 38.3483 38.5170 38.9100

38.9861 38.4538 38.6688 38.8781 39.3363

39.609939.1328 39.3694 39.8682

40.336439 .991240 .5057

41.165641 .2488

42.0975

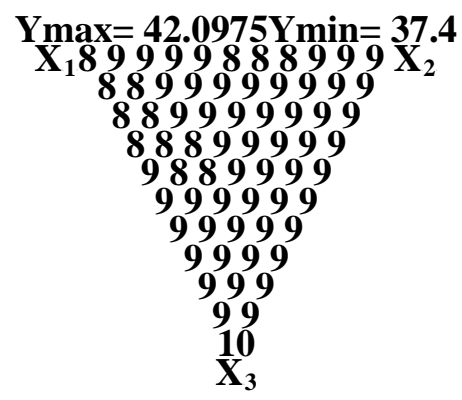

Fig. 6. Soil total porosity (\%), as affected by cheese whey + SAP, biochar+ SAP and compost + SAP after wheat crop. $Y \max =X_{1}=0, X_{2}=0, X_{3}=100 Y \min =X_{1}=100, X_{2}=0, X_{3}=0$ 
AVERAGE VALUES

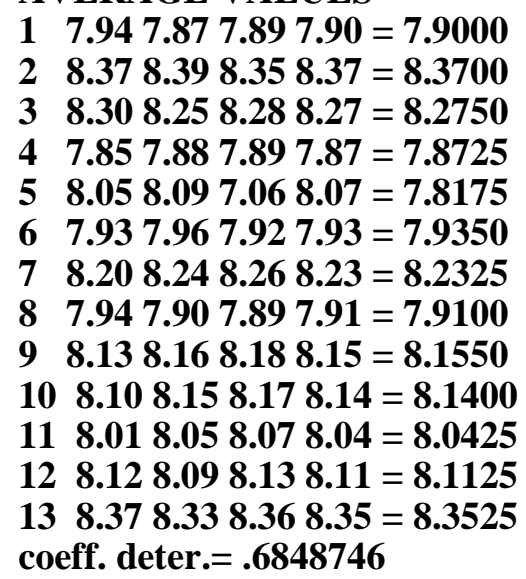

coeff. deter. $=.6848746$
correlation function $=.8275715$

criterion fisher $f(12,39)=7.063355$

soct $=.14167$

control $=.3077784$

$\mathbf{t}=\mathbf{1 . 4 5 2 9 1 7}$

control $=-7.525277$

$\mathrm{t}=35.52428$

control=-15.755

$\mathbf{t}=\mathbf{7 4 . 3 7 4}$

7.9000 7.8373 7.6422 7.43577.3388 7.8175

7.8772 7.9623 8.0728 8.2087 8.3700

7.8826 7.9117 7.7883 7.6334 7.5678 8.0596

8.1153 8.1784 8.2491 8.3281

7.8774 7.9782 7.9063 7.7827 8.0259 8.0701

8.1039 8.3072 8.2934

7.8844 8.0367 7.9962 7.8838 7.9344 8.1767

8.34418 .2659

7.9036 8.0873 8.0579 7.9366 8.1999 8.3597

8.2456

7.9350 8.1299 8.0916 8.1733 8.3541 8.2325

7.9786 8.1645 8.0971 8.3273 8.2266

8.0344 8.1912 8.2792 8.2279

8.1024 8.2099 8.2364

8.1826 8.2521

8.2750

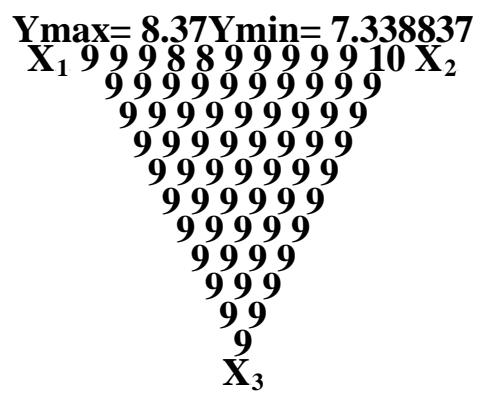

Fig. 7. Soil $\mathrm{pH}$ as affected by cheese whey + SAP, biochar + SAP and compost + SAP after wheat crop. $Y$ max $=X_{1}=0 \quad X_{2}=100 \quad X_{3}=0 Y$ mini $=X_{1}=60 X_{2}=40 \quad X_{3}=0$ 
AVERAGE VALUES

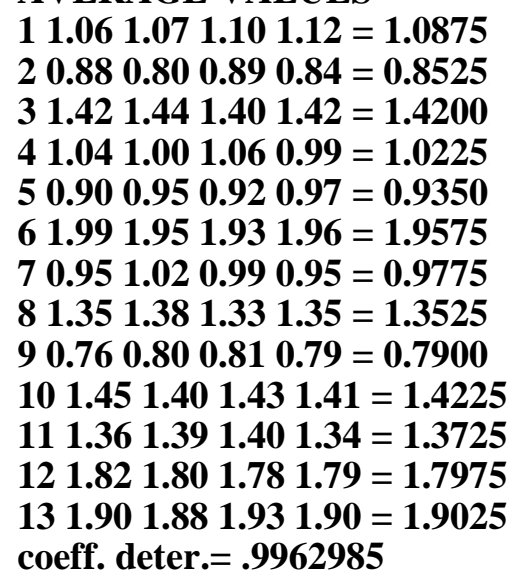

coeff. deter. $=.9962985$
correlation function $=.9981476$

criterion fisher $f(12,39)=874.7705$

soct $=2.690721 \mathrm{E}-02$

control $=.678889$

$\mathbf{t}=7.353703$

control $=-1.607222$

$\mathbf{t}=\mathbf{1 7 . 4 0 9 3 8}$

control=-2.235

$t=24.20945$

1.08751 .01500 .80810 .55060 .32660 .9350

0.91290 .89360 .87710 .86340 .8525

1.37411 .31791 .11320 .84400 .59431 .3180

1.18991 .01040 .77960 .8521

1.60441 .55051 .33411 .03921 .28431 .1013

0.81291 .25360 .8644

1.77841 .71281 .47071 .13610 .95241 .3478

1.60250 .8894

1.89611 .80481 .52301 .13471 .61971 .8262

0.9271

1.95751 .82651 .49101 .62871 .92480 .9775

1.96261 .77791 .37471 .89831 .0406

1.91141 .65901 .74661 .1164

1.80391 .46981 .2049

1.64011 .3061

1.4200

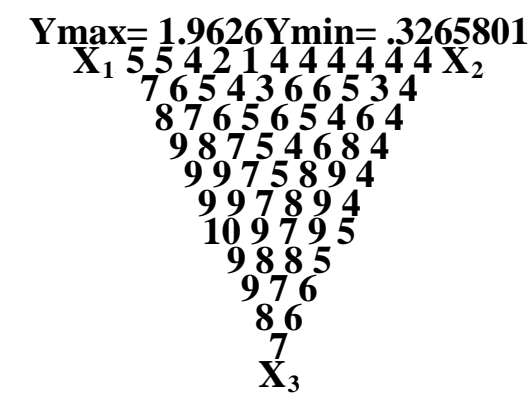

Fig. 8. Soil EC dS.m ${ }^{-1}$ as affected by cheese whey + SAP, biochar + SAP and compost + SAP after wheat crop. $Y \max =X_{1}=40 X_{2}=0 X_{3}=60 Y$ mini $=X_{1}=60 X_{2}=40 X_{3}=0$ 
Results in Table 4 and Fig. 9 indicate that application different combination of $\mathrm{X}_{1}$ (cheese whey + SAP), $X_{2}$ (biochar + SAP) and $X_{3}$ (compost + SAP) augmented soil organic matter content compared with the control. The maximum soil organic matter was obtained by the single compost treatment which recorded $0.20 \%$. The other single treatment of cheese whey and biochar resulted 60 and $50 \%$ of the maximum i.e. 0.12 and $0.11 \%$, respectively. Fig. 9 demonstrate that in addition to the beneficial effect of applied compost on soil physical and chemical properties, it showed likewise an enhancing effect on raising the soil organic matter. It is considered as an ultimate source of micronutrients and microbial activity. These results are supported by Sparks (1995), Giusquiani et al. (1995) and Sarwar et al. (2003).

Soil moisture content (saturation percentage, SP, field capacity, FC, wilting point, WP and available water, AW) followed the same trend, as noted from the output computer sheet, so, available water has been selected to represent these moisture characters which show a highly significant correlation coefficient $(r=0.90,0.93$ and 0.72),respectively. Results in Table 4 and Fig. 10 reveal that soil available water ranged between 4.31 and $8.11 \%$; the maximum soil available water $8.11 \%$ was occurred by 10,10 and $80 \%$ of the $X_{1}$ (cheese whey $+\mathrm{SAP}$ ), $\mathrm{X}_{2}$ (biochar + SAP) and $\mathrm{X}_{3}$ (compost + SAP), respectively. Application of single treatment of $\mathrm{X}_{1}$ (cheese whey $\left.+\mathrm{SAP}\right), \mathrm{X}_{2}$ (biochar $+\mathrm{SAP}$ ) and $\mathrm{X}_{3}$ (compost + SAP) resulting a soil available water equals 70,80 and $90 \%$ of the maximum soil available water, respectively. Thus, the increased soil available water took the following descending order (compost + SAP) $>$ (biochar + SAP) $>$ (cheese whey + SAP). Moreover, Fig. 10 show that the soil available water decreased gradually in the triangle from the $\mathrm{X}_{1}$ (cheese whey $+\mathrm{SAP}$ ) head toward the $\mathrm{X}_{2}$ (biochar + SAP) and $\mathrm{X}_{3}$ (compost $+\mathrm{SAP}$ ), this observation emphasizing the role of $\mathrm{X}_{3}$ in raising soil water retention.

The obtained results stated that application of compost has a marked pronounced useful effect on soil moisture characters. Similar results have been reported by Mohamed (2011) who indicated that the water holding capacity of sandy soil was increased with animal manure. Tom (2006) stated that soil organic matter enhances soil water retention because of its hydrophilic nature and its positive influence on soil structure, increasing soil organic matter increase soil aggregate formation, enhance infiltration, water retention and the pores that retain plant available water. The role of soil natural amendment in improving soil water retention doesn't depend only on its highly water adsorption property, but also on its ability to form aggregates.

Results in Table 5 represent grains yield (ton fad. ${ }^{-1}$ ), straw yield (ton fad. ${ }^{-1}$ ) biological yield (ton fad. ${ }^{-1}$ ), weight of 1000 grain (g), plant height $(\mathrm{cm})$ and spike length $(\mathrm{cm})$ as affected by all the possible combinations of $\mathrm{X}_{1}$ (cheese whey + SAP), $\mathrm{X}_{2}$ (biochar + SAP) and $\mathrm{X}_{3}$ (compost $+\mathrm{SAP})$. Obtained results reveal that all growth characters showed an increase by the application of soil amendments as compared to control treatment. However, the results showed that the application of $\mathrm{X}_{3}$ (compost +SAP) has more pronounced effect on wheat growth characters as compared to $\mathrm{X}_{1}$ (cheese whey +SAP) or $\mathrm{X}_{2}$ (biochar +SAP).

On the other hand, all the wheat growth characters appeared the same triangle trend and have a highly significant correlation coefficient with grains yield $(r=0.70,0.93,0.88,0.74$ and 0.76 ), respectively. Therefore, grains yield (ton fad. $^{-1}$ ) Fig. 11 was chosen to represent these group of wheat growth characters.

Scanning the output computer sheet in which all possible combination of $\mathrm{X}_{1}$ (cheese whey + SAP), $X_{2}$ (biochar + SAP) and $X_{3}$ (compost + $\mathrm{SAP}$ ) on wheat grain yield, it could be detected that the maximum which indicated by number 10 on the triangle (2.37 ton fad. $\left.{ }^{-1}\right)$ obtained with 10,10 and $80 \%$ of $X_{1}, X_{2}$ and $X_{3}$ respectively. The single treatment of $\mathrm{X}_{1}, \mathrm{X}_{2}$ and $\mathrm{X}_{3}$ resulted 70,70 and $90 \%$ of the maximum grain yield. These results suggest that application of (compost +SAP) in combination with (cheese whey + SAP), and (biochar + SAP) has more beneficial effects on wheat grain yield. In this contexts application of single treatment of $\mathrm{X}_{1}$, $\mathrm{X}_{2}$ and $\mathrm{X}_{3}$ resulted grain yield equal to 1.82, 1.72 and 2.22 ton fad. ${ }^{-1}$,respectively. Whereas control recorded 1.53 ton fad ${ }^{-1}$. These results are in agreement with many investigators, Tanveer et al. (2010) found that the maximum 
AVERAGE VALUES
$10.100 .130 .140 .12=0.1225$
$20.120 .090 .130 .11=0.1125$
$30.210 .180 .220 .20=0.2025$
$40.100 .100 .120 .10=0.1050$
$50.160 .130 .130 .15=0.1425$
$60.120 .120 .140 .12=0.1250$
$70.150 .130 .160 .14=0.1450$
$80.160 .150 .160 .15=0.1550$
$90.120 .130 .100 .13=0.1200$
$100.150 .160 .180 .16=0.1625$
$110.130 .130 .150 .13=0.1350$
$120.130 .150 .170 .15=0.1500$
$130.160 .130 .140 .15=0.1450$
coeff. deter. $=.8116753$

correlation function $=.9009302$

criterion fisher $f(12,39)=14.00743$

soct $=1.356355 \mathrm{E}-02$

control=-1.666668E-02

$\mathrm{t}=.2542753$

control $=-.1566667$

$t=2.390186$

control $=-.3$

$\mathrm{t}=4.576952$

0.12250 .15910 .16700 .14750 .10140 .1425

0.14050 .13650 .13050 .12250 .1125

0.11700 .15190 .15800 .13640 .08810 .1331

0.12850 .12410 .11970 .1170

0.11450 .14750 .15160 .12780 .13090 .1238

0.11880 .12620 .1225

0.11500 .14600 .14780 .12160 .10980 .1265

0.13350 .1290

0.11850 .14730 .14670 .11790 .13470 .1414

0.1365

0.12500 .15140 .14820 .14330 .15010 .1450

0.13450 .15830 .15240 .15960 .1545

0.14700 .16800 .16970 .1650

0.16250 .18060 .1765

0.18100 .1890

0.2025

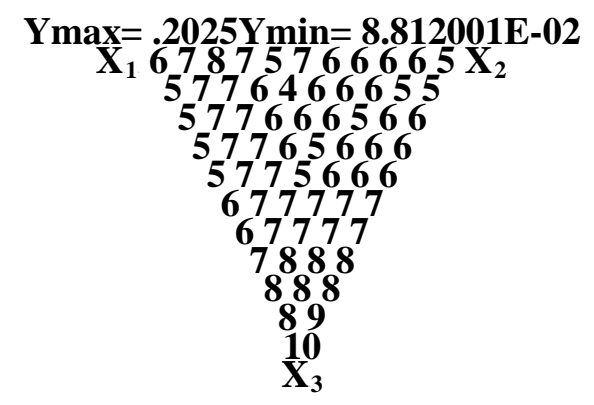

Fig. 9. Soil organic matter (\%) as affected by cheese whey + SAP, biochar + SAP and compost + SAP after wheat crop. $Y$ max $=X_{1}=0 \quad X_{2}=0 \quad X_{3}=100 Y$ mini $=X_{1}=50 \quad X_{2}=40 \quad X_{3}=10$ 
AVERAGE VALUES

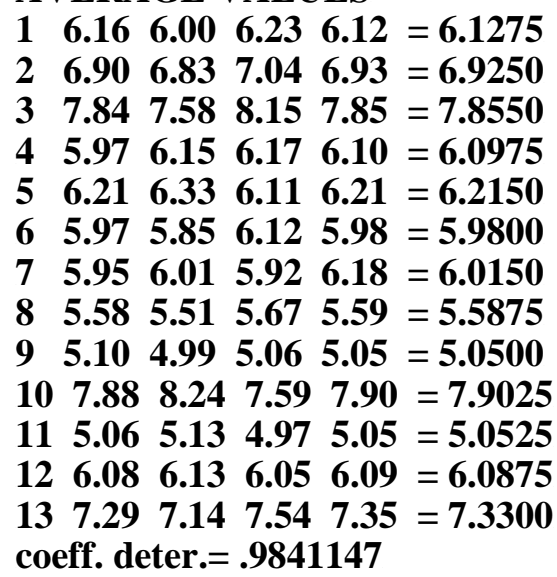

coeff. deter. $=.9841147$
correlation function $=.9920256$

criterion fisher $f(12,39)=201.3418$

soct $=\mathbf{. 1 3 0 9 8 0 8}$

control $=.7997217$

$\mathrm{t}=3.92624$

control $=-5.598055$

$\mathrm{t}=\mathbf{2 7 . 4 8 3 6 9}$

control=-10.8525

$\mathbf{t}=\mathbf{5 3 . 2 8 0 4 2}$

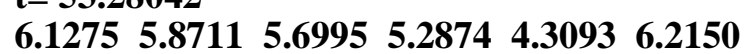

6.30726 .42436 .56636 .73326 .9250

$\begin{array}{llllll}5.9362 & 5.6775 & 5.5578 & 5.2518 & 4.4341 & 5.0967\end{array}$

$5.13915 .25675 .4493 \quad 6.5230$

$\begin{array}{llllll}5.8258 & 5.6190 & 5.6055 & 5.4599 & 5.0651 & 4.9828\end{array}$

$5.0257 \quad 6.0916$
6.2310

$\begin{array}{lllll}5.7963 & 5.6957 & 5.8425 & 5.9115 & 5.6542 \\ 6.1195\end{array}$

6.64636 .0490

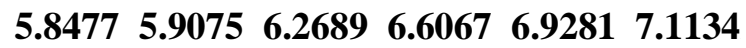

5.9770

$5.98006 .2544 \quad 6.8846 \quad 7.4515 \quad 7.4929 \quad 6.0150$

6.1932 6.73647 .68977 .78486 .1630

6.48737 .35357 .98916 .4210

6.86238 .10586 .7890

7.31827 .2670

7.8550

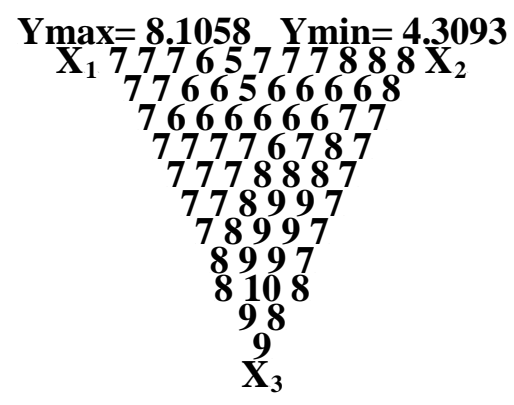

Fig. 10. Soil available water (AW) (\%) as affected by cheese whey + SAP, biochar+ SAP and compost + SAP after wheat crop. $Y \max =X_{1}=10 \quad X_{2}=10 \quad X_{3}=80 \quad Y \min =X_{1}=60 \quad X_{2}=40$ $\mathbf{X}_{3}=\mathbf{0}$ 
Table 5. Some wheat yield characters as affected by different combination of used amendments

\begin{tabular}{|c|c|c|c|c|c|c|c|c|c|}
\hline \multirow{2}{*}{$\begin{array}{c}\text { Treat. } \\
\text { No. }\end{array}$} & \multicolumn{3}{|c|}{ Treatment percentages (\%) } & \multirow{2}{*}{$\begin{array}{l}\text { Grains yield } \\
\left.\text { (ton fad. }{ }^{-1}\right)\end{array}$} & \multirow{2}{*}{$\begin{array}{c}\text { Straw yield } \\
\left(\text { ton fad. }{ }^{-1}\right)\end{array}$} & \multirow{2}{*}{$\begin{array}{c}\text { Biology } \\
\text { Yield } \\
\text { (ton fad. }^{-1} \text { ) }\end{array}$} & \multirow{2}{*}{$\begin{array}{l}\text { Weight of } 1000 \\
\text { grains } \\
\text { (g) }\end{array}$} & \multirow{2}{*}{$\begin{array}{l}\text { Plant height } \\
\text { (cm) }\end{array}$} & \multirow{2}{*}{$\begin{array}{r}\text { Spike } \\
\text { length } \\
\text { (cm) }\end{array}$} \\
\hline & $\begin{array}{c}\mathrm{X}_{1} \\
\text { Cheese } \\
\text { whey+SAP }\end{array}$ & $\begin{array}{c}\mathbf{X}_{2} \\
\text { Biochar } \\
+\mathrm{SAP} \\
\end{array}$ & $\begin{array}{c}\mathrm{X}_{3} \\
\text { Compost } \\
+\mathrm{SAP} \\
\end{array}$ & & & & & & \\
\hline 1 & 100 & 0.0 & 0.0 & 1.82 & 2.79 & 4.61 & 40.94 & 75.70 & 10.00 \\
\hline 2 & 0.0 & 100 & 0.0 & 1.72 & 2.88 & 4.60 & 37.33 & 74.87 & 9.52 \\
\hline 3 & 0.0 & 0.0 & 100 & 2.22 & 3.27 & 5.49 & 54.86 & 85.92 & 12.22 \\
\hline 4 & 33.3 & 33.3 & 33.3 & 2.05 & 2.88 & 4.93 & 52.40 & 78.45 & 11.70 \\
\hline 5 & 50 & 50 & 0.0 & 2.04 & 3.02 & 5.06 & 45.53 & 75.95 & 11.47 \\
\hline 6 & 50 & 0.0 & 50 & 2.14 & 3.09 & 5.23 & 48.34 & 83.35 & 11.32 \\
\hline 7 & 0.0 & 50 & 50 & 2.08 & 2.93 & 5.01 & 44.41 & 79.17 & 11.62 \\
\hline 8 & 66.6 & 16.6 & 16.6 & 2.10 & 2.84 & 4.94 & 50.09 & 78.02 & 10.25 \\
\hline 9 & 16.6 & 66.6 & 16.6 & 2.09 & 2.95 & 5.04 & 46.60 & 75.92 & 10.67 \\
\hline 10 & 16.6 & 16.6 & 66.6 & 2.37 & 3.19 & 5.56 & 55.11 & 83.07 & 11.70 \\
\hline 11 & 44.4 & 44.4 & 11.1 & 2.11 & 2.92 & 5.03 & 46.03 & 76.90 & 11.47 \\
\hline 12 & 44.4 & 11.1 & 44.4 & 2.12 & 3.01 & 5.13 & 50.37 & 80.25 & 11.60 \\
\hline 13 & 11.1 & 44.4 & 44.4 & 2.07 & 3.11 & 5.18 & 49.10 & 78.07 & 11.75 \\
\hline \multicolumn{4}{|l|}{ Control } & 1.53 & 1.91 & 3.44 & 39.18 & 63.50 & 7.10 \\
\hline \multicolumn{4}{|c|}{ Correlation coefficients with grains yield (ton fad. ${ }^{-1}$ ) } & - & 0.70 & 0.93 & 0.88 & 0.74 & 0.76 \\
\hline
\end{tabular}


AVERAGE VALUES

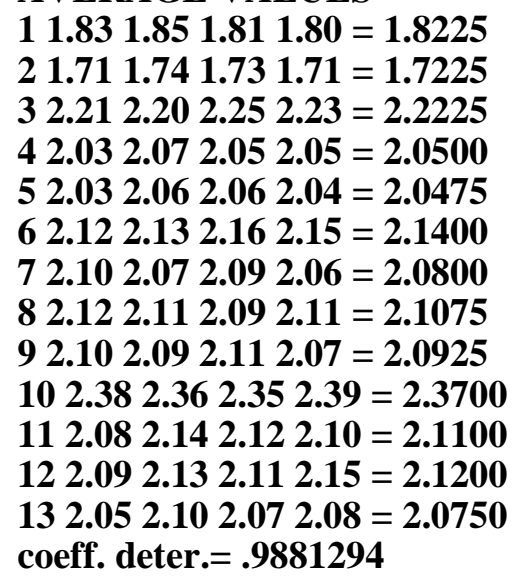

coeff. deter. $=.9881294$
correlation function $=.994047$

criterion fisher $f(12,39)=270.5365$

soct $=\mathbf{. 0 1 9 4 4 9 7}$

control $=.2033335$

$\mathrm{t}=\mathbf{2 . 5 9 0 5 6 3}$

control $=-2.02$

$t=25.73574$

control $=-4.231667$

$\mathbf{t}=\mathbf{5 3 . 9 1 3 4}$

1.82252 .04272 .23672 .26461 .98652 .0475

2.02651 .98351 .91851 .83151 .7225

1.90482 .03462 .16142 .14551 .84692 .0997

2.07922 .04391 .99401 .8112

1.97772 .04042 .12342 .08692 .13502 .1297

2.11701 .99211 .8913

2.04122 .06012 .12262 .08892 .09152 .1055

2.00861 .9628

2.09532 .09362 .15902 .15142 .13942 .0435

2.0257

2.14002 .14112 .23262 .21872 .09682 .0800

2.17532 .20262 .34342 .16852 .1257

2.20122 .27792 .25862 .1628

2.21772 .36712 .1913

2.22482 .2112

2.2225

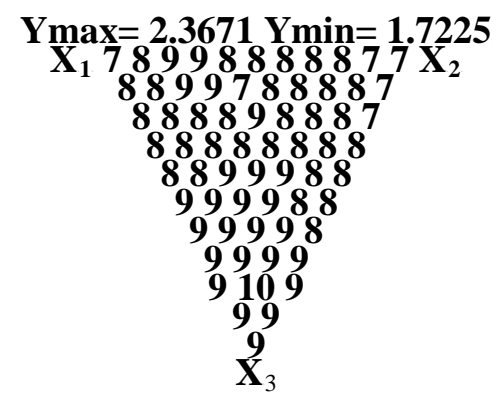

Fig. 11. Grain yield of wheat plant (ton fad..$\left.^{-1}\right)$ as affected by cheese whey + SAP, biochar + SAP and compost + SAP after wheat crop. $Y$ max $=X_{1}=10 \quad X_{2}=10 \quad X_{3}=80 Y \min =X_{1}=0 \quad X_{2}=100$ $\mathbf{X}_{3}=\mathbf{0}$ 
wheat grain yield of $4083 \mathrm{Kg} \mathrm{ha}^{-1}$ induced with the application of compost. Tayebeh et al. (2010) reported that using combination of organic and inorganic fertilizer achieved a highest yield without negative effect on seed quality. Duong (2013) found that compost increased plant growth and nutrient uptake with increasing $\mathrm{N}$ and $\mathrm{P}$ availability whereas plant growth achieved the maximal after 4 months. The studies of Abou-Hadid et al. (2001), Nweke and Nsoanya (2013) and Nweke et al. (2014) showed that the application of organic amendments to soils increases yield of crops and improves soil parameters and the ability of the soil to hold plant nutrient elements. Mohamed (2007) found that grains and straw yields of wheat were increased due to application of the cheese whey at a rate of $210 \mathrm{~m}^{3} / \mathrm{fad}$.

\section{REFERENCES}

Abou-Hadid, A.F., O.M. Anim, A.I. Abel Fattah and M.S. Ezzat (2001). Effect of composted greenhouse wastes on macro-nutrient concentration and productivity of cucumber Acta. Hort., 549: 123-130.

Agegnehu, G., M.I. Bird, P.N. Nelson and A.M. Bass (2015). The ameliorating effects of biochar and compost on soil quality and plant growth on a Ferralsol. Soil Res., 53(1): 1-12.

Baruah, T.C. and H.P. Barthakur (1997). A textbook of soil analysis. Dept. Soil Sci. Assam Agric. Univ. Jorhat. India.

Basyouny, E.A. (2002). Significance of applied organic maturing in some newly reclaimed areas under different water qualities. Fayoum. J. Agric., Res. Dev., 16: 163-201.

Black, C.A. (1965). Method of Soil Analysis, Part 2, Chemical and Microbiological Properties, Ame. Soc. Agron., Inc., Publisher, Madison, Wisconsin USA,.

Cottenie, A., M. Verloo, L. Kiekens, G. Velghe and R. Amertynck (1982). Chemical analysis of plants and soils. Laboratory of Analytical and Agrochemistry State Univ., Ghent, Belgium., 50-70.

Deleenheer, L. and M. De Boodt (1965). Soil physical international training center for post, Grandnaty Soil Sci. Tests, Gent, Belgium.
Demir, Z. and C. Gulser (2015). Effects of rice husk compost application on soil quality parameters in greenhouse conditions. Eurasian J. Soil Sci., 4 : 225-231.

Duong, T.T.T. (2013). Compost effects on soil properties and plant growth. Ph.D. Thesis, Adelaide Univ., School Agric., Food and Wine.

Ekebafe, M.O., L.O. Ekebafe and M. Maliki (2013). Utilization of biochar and superabsorbent polymers for soil amendment. Sci. Prog., 96 (1): 85-94.

El-Fayoumy, M.E., E.I. El-Maddoh and H.M. Ramadan (2000). Effects of sludge-sulfur applications as soil amendments on some Egyptians soil properties and productivity of wheat and corn. Egypt. J. Appl. Sci., 15: 323349.

El-Maddah, E.I. (2005) Amelioration of some chemical properties and productivity of wheat and maize plants using different sources of soil amendments at El-Gharbia Governorate. Egypt, J. Appl. Sci., 20: 731-761.

Giusquiani, P.L., M. Pagliai, G. Gigliotti, D. Businelli and A. Benetti (1995). Urban waste compost: effects on physical, chemical, and biochemical soil properties. J. Environ. Quality, 24 (1): 175-182.

Gonzalez, E., R. Gomez, M. Comese, M. Quesada and M. Conti (2010). Influence of organic amendments on soil quality potential indicators in an urban horticultural sys-tem. Biore-source Technol., 101 : 8897-8901.

Inal, A., A Gunes, O. Sahin, M.B. Taskin and E.C. Kaya (2015). Impacts of biochar and processed poultry manure, applied to a calcareous soil, on the growth of bean and maize. Soil Use and Manag., 31 (1):106-113.

Jackson, M.L. (1973). Soil chemical Analysis. Prentice-Hall of Indian private, Limited, New Delhi.

Mahmoud, M.R. (2000). The role of organic wastes and potassium fertilizer in soil fertility and nutrients content of barley crop in sandy soils. J. Agric. Sci. Mansoura Univ., 25: 5941-5954. 
Miller, B.W.B., C.F. Drury, F.J. Larney and X. Hao (2015). Influence of long- Term (9 yr) composted and stockpiled feedlot manure application on selected soil physical properties of a clay loam soil in southern Alberta. Comp. Sci. and Utiliz., 23 (1): 1-10.

Mohamed, M.K. (2011). Water management in sandy soil using neutron scattering method. Ph. D. Thesis. Fac. Agric., Ain Shams Univ.

Mohamed, M.S.A. (2007). Using of nontraditional soil conditioners for improving properties and productivity of calcareous soils (Maryutarea). Ph. D. Thesis, Fac. Agric. Benha Univ., Egypt.

Moussa, K.F.S., N. Youssef and I.R. Mohamed (1986). A computer model on fertilizers application to plants. Egypt. Soc. Crop Sci. Proc. $2^{\text {nd }}$. Conf. Agron. Alex. Egypt., 1:649- 662.

Niklasch, H. and R.G. Joergensen (2001). Decomposition of peat, biogenic municipal waste compost, and shrub/grass compost added in different rates to a silt loam. J. Plant Nut. Soil Sci.

Nweke, I.A. and L.N. Nsoanya (2013). Effect of different rates of rice mill waste on soil chemical properties and grain yield of maize (Zea mays L.). Int'l J. Agric. and Rural Dev., 16 (11): 1431-1436.

Nweke, I.A., S.O. OkoliP and C.O. Enyioko (2014). Effect of different rates of poultry droppings and plant spacing on soil chemical properties and yield of cucumber. Elixir Int'l. J. Agric., 70 : 23934-23940.
Sarwar, G., N. Hussain, F. Mujeeb, H. Schmeisky and G. Hassan (2003). Biocompost application for the improvement of soil characteristics and dry matter yield of Loliumperenne (Grass). Asian J. Plant Sci., 2: 237-241.

Selvakumari, G., M. Baskar, D. Jayanthi and K.K. Mathan (2000). Effect of integration of Fly ash with fertilizers and organic manures on nutrient availability, yield and nutrient uptake of rice in alfi sols. J. Indian Soc. Soil Sci., 48: 268-278.

Sparks, D.L. (1995). Environmental Soil Chemistry. Acad. Press, San Decca.

Tanveer, S.K., S. Yasmin, I. Hussain and M.Y. Mujahid (2010). Wheat production and quality affected by different combinations of fertilizer NP and farmyard manure in rain fed area. Pak. J. Agric. Res., 23(1-2): 94- 97.

Tayebeh, A., A. Alemzadeh and S.A. Kazemeini (2010). Effect of organic and inorganic fertilizers on grain yield and protein banding pattern of wheat. Aust. J. Crop Sci., 4 (6): 384-389.

Tom, G.H. (2006). Available Water Capacity and Soil Organic Matter. Encyclopedia of Soil Sci.

Wahdan, A.A.A., A.A.A. Hassanien and N.G.M. Aziz (2005). An organic source and elemental sulfur inputs for calcareous soil management, barley yield and its components. Fayoum, J. Agric. Rec. Dev., 19: 148-162.

$$
\begin{aligned}
& \text { التأثثر التفاعلي لبعض محسنات التربة على جودة الأراضي الرملية المزروعة بالقمح } \\
& \text { نسرين محمد سامي محسن - محمود نبيل خليل- كرم فؤاد موسي - السيد احمد حسن الناقة }
\end{aligned}
$$

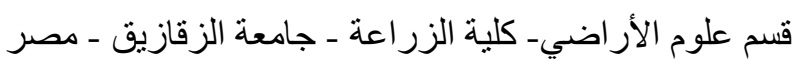

أجريت تجربة أصص بالصوبة الزجاجية لكلية الزراعة جامعة الزقازيق- مصر، واستخدمت التربة الرملية غير

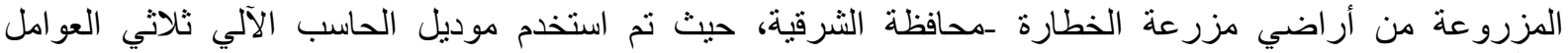

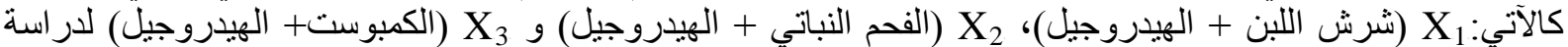

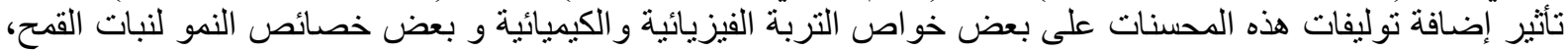

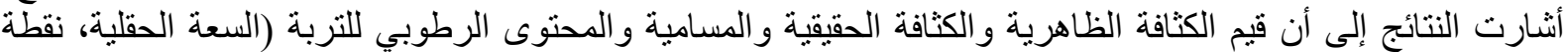

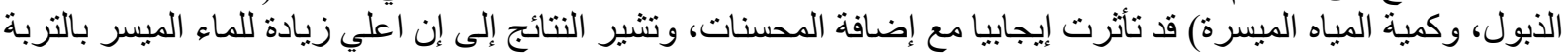

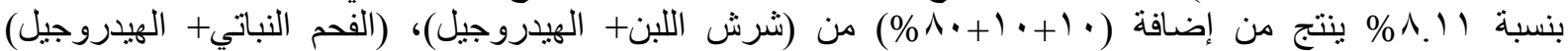

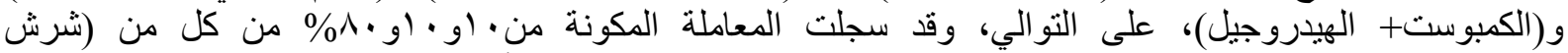

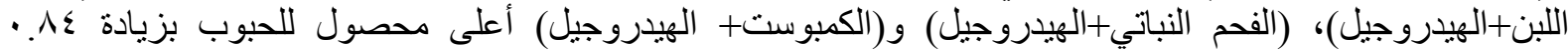
طن/فدان مقارنة بالكنترول.

$$
\text { أستاذ الأر اضي ـ كلية الزر اعة بشبين الكوم - جامعة المنوفية. }
$$

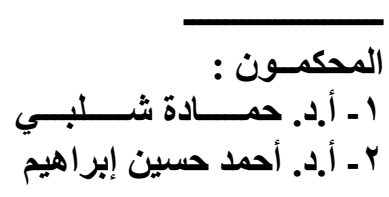

